\title{
PENGARUH PENAMBAHAN PATI BENGKOANG TERHADAP KARAKTERISTIK FISIK DAN MEKANIK EDIBLE FILM
}

\section{THE EFFECT OF ADDING YAM STARCH TOWARDS PHYSICAL AND MECHANICAL CHARACTERISTIC OF EDIBLE FILM}

\author{
Melanie Cornelia ${ }^{1)}$, Nuri Arum Anugrahati ${ }^{2)}$, Christina $^{3)}$ \\ Jurusan Teknologi Pangan, Universitas Pelita Harapan \\ JI. M. H. Thamrin Boulevard 1100, Lippo Karawaci, Tangerang \\ E-mail: melanie.cornelia@uph.edu
}

Received 27 Agustus 2012; revised 14 September 2012; accepted 24 September 2012

\begin{abstract}
ABSTRAK
Kegunaan edible film sebagai kemasan primer makanan semakin meningkat. Pati bengkoang dan tapioka dapat digunakan sebagai sumber pati dalam pembuatan edible film. Tujuan penelitian ini adalah untuk menentukan konsentrasi tapioka dan gliserol dan menentukan jenis asam lemak yang menghasilkan karakteristik fisik dan mekanik terbaik dari edible film dengan penambahan pati bengkoang. Pembuatan edible film dilakukan dengan menambahkan variasi konsentrasi tapioka dan gliserol dan dengan menambahkan $1 \%$ pati bengkoang. Pati bengkoang dapat menghasilkan edible film dengan elongasi yang cukup baik karena kandungan amilosa yang cukup tinggi yaitu $23 \%$. Pengaruh variasi konsentrasi tapioka dan gliserol terhadap ketebalan, lightness, kuat tarik, persen pemanjangan, dan laju transmisi uap air diamati. Hasil penelitian menunjukkan bahwa konsentrasi tapioka dan gliserol berpengaruh signifikan terhadap ketebalan, kuat tarik, persen pemanjangan, dan laju transmisi uap air. Peningkatan konsentrasi tapioka hingga $2 \%$ dan konsentrasi gliserol dari $0,5 \%$ hingga $1 \%$ dapat meningkatkan ketebalan dan persen pemanjangan. Peningkatan konsentrasi tapioka dan gliserol juga meningkatkan kuat tarik dan laju transmisi uap air. Edible film terbaik dihasilkan dari konsentrasi tapioka $2 \%$ dan gliserol $0.5 \%$, dalam penelitian ini jenis asam lemak yang digunakan adalah asam lemak stearat dan asam lemak oleat. Hasilnya menunjukkan bahwa jenis asam lemak juga berpengaruh signifikan terhadap lightness, kuat tarik, persen pemanjangan, dan laju transmisi uap air. Asam lemak stearat memberi pengaruh lebih baik pada karakteristik edible film dibandingkan dengan asam lemak oleat. Asam lemak stearat meningkatkan kuat tarik seiring dengan penurunan elongasi. Penambahan asam lemak stearat dapat menurunkan laju transmisi uap air edible film dari pati bengkoang walaupun dengan penurunan persen pemanjangan.
\end{abstract}

Kata kunci : Edible film, Pati bengkoang, Asam lemak, Kuat tarik, Persen pemanjangan

\begin{abstract}
Utilization of edible film as primary food packaging has been increasing in a recent year. Yam starch and tapioca can be used as source of starch for making edible film. The objectives of this research were to determine the concentration of tapioca and glycerol and also to determine types of fatty acid for making edible film made from yam starch with the best physical and mechanical characteristic by adding yam starch. In this research tapioca and glycerol with some various concentration were added into mixture of edible film made from $1 \%$ yam starch. Yam starch could give better elongation in edible film due to high amylase content (23\%). The effect of tapioca and glycerol concentration was observed on thickness, lightness, tensile strength, elongation, and water vapor transmission rate. The result showed that interaction between tapioca and glycerol concentration significantly affect thickness, tensile strength, elongation, and water vapor transmission rate while the tapioca and glycerol independently affect the lightness. Increasing concentration of tapioca to $2 \%$ and glycerol from $0.5 \%$ to $1 \%$ increased the thickness and elongation as well as the tensile strength and water vapor transmission rate. The best edible film was made from $2 \%$ tapioca and $0.5 \%$ glycerol. Two types of fatty acids were added to the best formulation of edible film were also evaluated. The result showed that types of fatty acid affect the lightness, tensile strength, elongation, and water vapor transmission rate. Stearic acid has good effect for edible film characteristic than oleic acids. Stearic acids increase the tensile strength while elongation decreases. Addition of stearic acid can decrease the water vapor transmission rate of edible film contain yam starch although the elongation decreases.
\end{abstract}

Key words : Edible film, Yam starch, Fatty acid, Tensile strength, Elongation 
Edible film merupakan salah satu bahan pengemas yang dapat digunakan sebagai alternatif plastik pada kemasan bahan dan produk pangan. Pemanfaatan edible film sebagai bahan pengemas pada makanan segar dan olahan semakin meningkat dengan banyaknya penelitian mengenai edible film tersebut (Baker et al., 1994). Menurut Krochta dan De Mulder-Johnston (1997), edible film dapat berfungsi sebagai barrier terhadap perpindahan massa (seperti kelembaban, oksigen, lipida, dan zat terlarut) sehingga dapat mempertahankan mutu dan umur simpan bahan atau produk pangan.

Sumber pati yang dapat dimanfaatkan sebagai bahan pembuatan edible film diantaranya adalah pati bengkoang dan tapioka. Pati bengkoang dapat menghasilkan edible film dengan elongasi yang cukup baik karena kandungan amilosa yang cukup tinggi yaitu 23\%. Edible film dari tapioka mempunyai karakteristik kuat tarik yang cukup baik tetapi kekurangannya adalah persen pemanjangan yang kurang baik dan transmisi uap air yang cukup tinggi (Matsui et al., 2004).

Menurut Chillo et al. (2008), gliserol merupakan plasticizer yang ditambahkan dalam pembuatan edible film. Gliserol berfungsi untuk mengurangi kekakuan pada edible film sehingga film yang dihasilkan lebih fleksibel. Menurut Chen et al. (2009), edible film berbasis polisakarida pada umumnya memiliki sifat penghalang uap air yang kurang baik. Penambahan komponen hidrofobik seperti asam lemak diharapkan dapat memperbaiki sifat ketahanan terhadap uap air dan menghasilkan karakeristik edible film dari pati bengkoang yang lebih baik. Tujuan penelitian adalah menentukan konsentrasi tapioka dan gliserol serta jenis asam lemak yang dapat menghasilkan edible film dengan karakteristik fisik dan mekanik terbaik yang dihasilkan dari penambahan $1 \%$ pati bengkoang.

\section{BAHAN DAN METODE}

\section{Bahan}

Bahan yang dibutuhkan adalah pati bengkoang, tapioka, CMC, gliserol (food grade), asam lemak stearat (food grade), asam lemak oleat (food grade), dan akuades. Bengkoang diperoleh dari Pasar Sinpasa Gading Serpong, Tangerang.

Bahan kimia yang dibutuhkan untuk analisis adalah bahan pro analyst yang meliputi Na-tiosulfat $0,1 \mathrm{~N}$, asam perklorat $52 \%, \mathrm{~K}_{2} \mathrm{SO}_{4}$, $\mathrm{HgO}, \mathrm{H}_{3} \mathrm{BO}_{3}, \mathrm{Al}(\mathrm{OH})_{3}$ atau $\mathrm{Pb}$-asetat, aseton, benzena, $\mathrm{NaOH} 1,5 \mathrm{~N}, \mathrm{H}_{2} \mathrm{SO}_{4} 0,3 \mathrm{~N}, \mathrm{KI} 20 \%$, $\mathrm{H}_{2} \mathrm{SO}_{4} 26,5 \%, \mathrm{NaOH} 0,1 \mathrm{~N}, \mathrm{BaCl}_{2}$. Selain itu larutan Fehling $A$, larutan Fehling $B$, indikator pati, indikator phenolphthalein, buffer $\mathrm{pH} 4$ dan $\mathrm{pH} 7$, dan silica gel juga digunakan dalam proses analisis.

Alat yang digunakan untuk ekstraksi pati adalah blender, beaker glass, kain saring, ayakan $80 \mathrm{mesh}$, dan cabinet dryer. Alat yang digunakan dalam pembuatan edible film adalah beaker glass, timbangan analitik, gelas ukur, heater, magnetic stirrer, termometer, timbangan analitik, plat $(38,5 \mathrm{~cm} \times 27,3 \mathrm{~cm} \times 1,5 \mathrm{~cm})$, dan cabinet dryer. Alat yang digunakan untuk analisis adalah pipet, tanur, tabung kondensor, oven, aluminium foil, desikator, cabinet dryer, heater, tabung reaksi, kertas saring, cawan penguapan, cawan pengabuan, labu erlenmenyer, buret, corong, batu didih, alat ekstraksi Soxhlet, dan alat Kjeldahl. Alat yang digunakan untuk uji fisik dan mekanik edible film adalah Lloyds instrument, mikrometer, kromameter (Minolta Cr-400), desikator, dan timbangan analitik.

Rancangan percobaan penelitian tahap I adalah rancangan acak lengkap 2 faktor yang disusun 3 level $x \quad 2$ level dengan 4 kali pengulangan. Uji statistik yang digunakan adalah one way annova. Rancangan percobaan penelitian selanjutnya disusun 1 faktor $x 2$ level dengan 4 kali pengulangan. Statistik yang digunakan adalah Independent T-Test.

\section{Metode}

Proses Ekstraksi Pati Bengkoang (Hasbullah, 2000)

Proses ekstraksi diawali dengan bengkoang dikupas kemudian dicuci. Bengkoang yang telah dikupas kemudian dihancurkan (ditambah air 1:1) menjadi bubur bengkoang. Bubur bengkoang yang dihasilkan kemudian disaring dan diambil cairan pastanya. Cairan pasta tersebut diendapkan selama 4-5 jam. Pasta bengkoang hasil pengendapan dikeringkan pada suhu $50^{\circ} \mathrm{C}$ selama 8 jam kemudian dihancurkan dan diayak (80 mesh).

\footnotetext{
Proses Pembuatan Edible Film dari Pati Bengkoang dengan Konsentrasi Tapioka dan Gliserol yang Berbeda

Edible film dibuat dengan konsentrasi tapioka dan gliserol yang berbeda. Proses pembuatan edible film dari pati bengkoang dapat dilihat pada Gambar 1 dan formulasi pembuatan edible film dapat dilihat pada Tabel 1.
} 


\author{
Tapioka*) \\ $(1 \%, 2 \%$, dan $3 \%)$ \\ Pelarutan dalam air $(200 \mathrm{~mL})$ \\ $\downarrow$ \\ Pemanasan pada suhu $64^{\circ} \mathrm{C}$ dengan \\ pengadukan konstan \\ $\downarrow$ \\ Penambahan pati bengkoang dan CMC (dry mix) \\ Pengadukan konstan selama 5 menit \\ $\downarrow$ \\ Penambahan gliserol $\left.{ }^{\star *}\right)$ \\ $(0,5 \%$ dan $1 \%)$ \\ Pengadukan konstan selama 1 menit \\ $\downarrow$ \\ Pencetakan pada plat dengan ukuran $38,5 \mathrm{~cm} \times$

$$
27,3 \mathrm{~cm} \times 1,5 \mathrm{~cm}
$$ \\ $\downarrow$ \\ Pengeringan dengan cabinet dryer pada suhu \\ $60^{\circ} \mathrm{C}$ selama 8 jam$$
\downarrow
$$ \\ Edible film
}

Gambar 1. Proses pembuatan edible film dari pati bengkoang. (Sumber: Budiman (2011) dengan modifikasi)

Keterangan: $\left.{ }^{*}\right),{ }^{* *}$ ) sesuai perlakuan pada Tabel 1

Tabel 1. Formulasi pembuatan edible film (Sumber: Budiman (2011) dengan modifikasi)

\begin{tabular}{cc}
\hline Bahan & Jumlah \\
\hline Pati bengkoang & $1 \%$ \\
Tapioka & Sesuai perlakuan \\
CMC & $0,4 \%$ \\
Gliserol & Sesuai perlakuan \\
\hline
\end{tabular}

Proses Pembuatan Edible Film dari Pati Bengkoang dengan Jenis Asam Lemak yang Berbeda

Edible film dengan konsentrasi tapioka dan gliserol terbaik ditambahkan dengan jenis asam lemak yang berbeda yaitu asam lemak stearat dan oleat. Proses pembuatan edible film dari pati bengkoang dengan jenis asam lemak yang berbeda dapat dilihat pada Gambar 2 dan formulasi pembuatan edible film dapat dilihat pada Tabel 2.

Tabel 2. Formulasi pembuatan edible film (Sumber: Budiman (2011) dengan modifikasi)

\begin{tabular}{ll}
\hline Bahan & Jumlah \\
\hline Pati bengkoang & $1 \%$ \\
Tapioka & Konsentrasi terbaik \\
CMC & $0,4 \%$ \\
Gliserol & Konsentrasi terbaik \\
Asam lemak stearat & $0,1 \%$ \\
atau oleat & \\
\hline
\end{tabular}

\author{
Tapioka \\ $\downarrow$ \\ Pelarutan dalam air $(200 \mathrm{~mL})$ \\ $\downarrow$ \\ Pemanasan pada suhu $64^{\circ} \mathrm{C}$ dengan \\ pengadukan konstan \\ $\downarrow$ \\ Pengadukan konstan selama 3 menit \\ $\downarrow$ \\ Penambahan pati bengkoang dan CMC (dry mix) \\ $\downarrow$ \\ Pengadukan konstan selama 5 menit \\ Penambahan gliserol \\ $\downarrow$ \\ Pengadukan konstan selama 1 menit \\ $\downarrow$ \\ Penambahan asam lemak stearat atau oleat \\ $\downarrow$ \\ Pengadukan selama 6 menit \\ $\downarrow$ \\ Pencetakan pada plat dengan ukuran $38,5 \mathrm{~cm} x$ \\ $27,3 \mathrm{~cm} \times 1,5 \mathrm{~cm}$ \\ $\downarrow$ \\ Pengeringan dengan cabinet dryer pada suhu \\ $60^{\circ} \mathrm{C}$ selama 8 jam \\ Edible film
}

Gambar 2. Proses pembuatan edible film dari pati bengkoang dengan jenis asam lemak stearat dan oleat (Sumber: Budiman (2011) dengan modifikasi)

\section{HASIL DAN PEMBAHASAN}

Pengaruh Konsentrasi Tapioka dan Gliserol terhadap Karakteristik Fisik Edible Film dari Pati Bengkoang

Pembuatan edible film dari pati bengkoang dilakukan dengan 3 konsentrasi tapioka yang berbeda yaitu $1 \%, 2 \%, 3 \%$ dan 2 konsentrasi gliserol yang berbeda yaitu $0,5 \%$ dan $1 \%$. Karakteristik fisik edible film yang diuji meliputi ketebalan dan lightness.

\section{Ketebalan}

Gambar 3 dapat dilihat bahwa konsentrasi gliserol $0,5 \%$ atau $1 \%$ meningkatkan ketebalan edible film seiring dengan peningkatan konsentrasi tapioka sampai $2 \%$. Konsentrasi tapioka yang semakin tinggi menunjukkan jumlah padatan terlarut yang lebih banyak. Jumlah padatan terlarut pada edible film yang semakin banyak menghasilkan edible film yang semakin tebal. Peningkatan konsentrasi pati menyebabkan peningkatan ketebalan film (McHugh dan Krochta, 1994). Peningkatan konsentrasi gliserol dari $0,5 \%$ ke $1 \%$ tidak mempengaruhi ketebalan edible film dengan konsentrasi tapioka 2\% dan 3\% (Gambar 3). Hal 
tersebut disebabkan pada konsentrasi tapioka yang lebih tinggi menunjukkan jumlah padatan terlarut lebih banyak sehingga pengaruh dari konsentrasi gliserol tidak terlihat. Gliserol merupakan jenis plasticizer yang bersifat hidrofilik sehingga pada konsentrasi yang tinggi dapat berinteraksi dengan air menghasilkan edible film yang lebih tebal (Chen dan Lai, 2008).

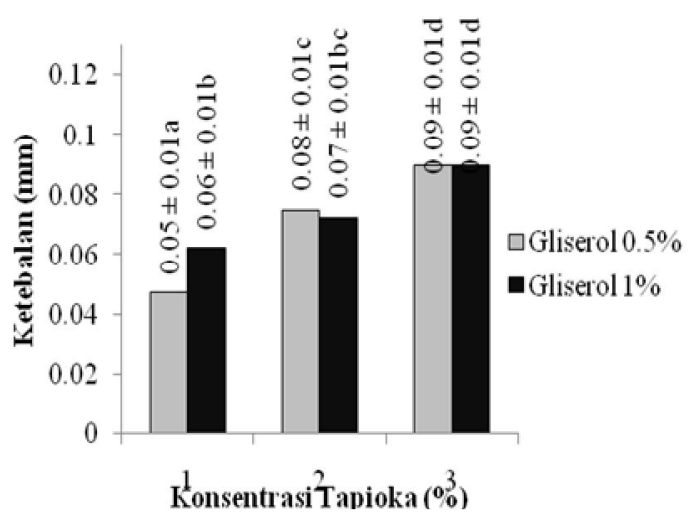

Gambar 3. Pengaruh konsentrasi tapioka dan gliserol terhadap ketebalan edible film dari pati bengkoang.

Keterangan: Angka yang diikuti dengan huruf yang berbeda menunjukkan beda nyata pada $p<0,05$.

\section{Lightness}

Gambar 4 menunjukkan peningkatan lightness edible film pada konsentrasi tapioka $1 \%$ dan $2 \%$. Peningkatan konsentrasi tapioka dari $2 \%$ sampai $3 \%$ tidak berpengaruh terhadap lightness edible film yang dihasilkan. Hal tersebut kemungkinan dapat dipengaruhi oleh konsentrasi tapioka dan proses gelatinisasinya.

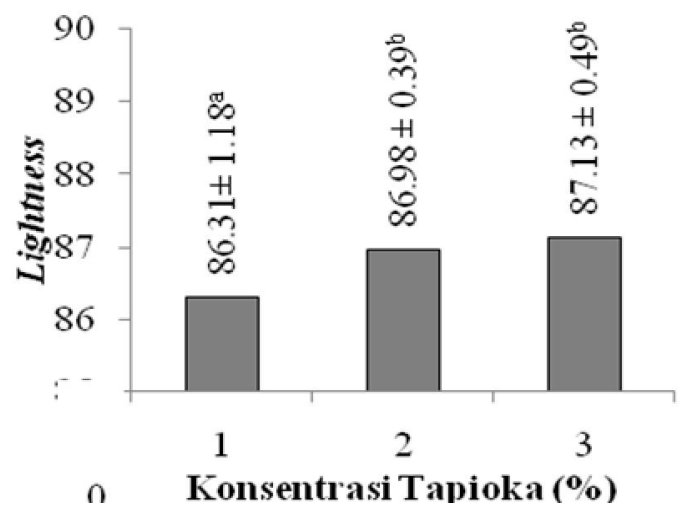

Gambar 4. Pengaruh konsentrasi tapioka terhadap lightness edible film dari pati bengkoang.

Keterangan: Angka yang diikuti dengan huruf yang berbeda menunjukkan beda nyata pada $p<0,05$.
Menurut Chen et al. (2009), tingkat lightness yang tinggi kemungkinan dapat berhubungan dengan amilopektin pada tapioka yang relatif tinggi dan amilosa yang rendah yang mengakibatkan swelling-solubility yang lebih tinggi. Hal tersebut menyebabkan film yang dihasilkan memiliki nilai lightness yang lebih tinggi.

Berdasarkan hasil analisis ANOVA konsentrasi gliserol berbeda signifikan terhadap lightness edible film. Gambar 5 menunjukkan konsentrasi gliserol $0,5 \%$ menghasilkan lightness yang lebih tinggi dibandingkan edible film dengan konsentrasi gliserol $1 \%$.

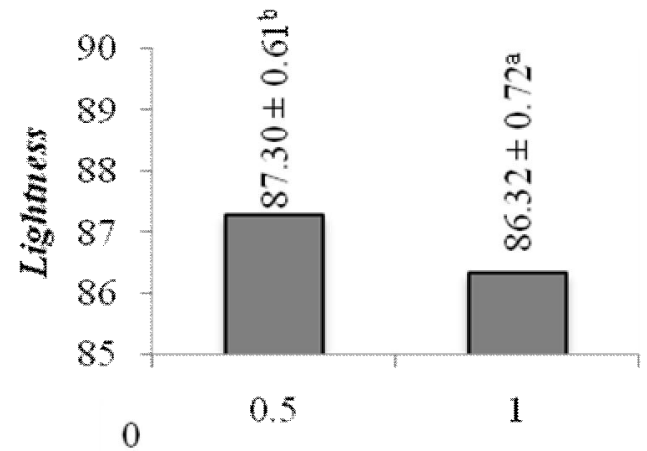

Konsentrasi gliserol $(\%)$

Gambar 5. Pengaruh konsentrasi gliserol terhadap lightness edible film dari pati bengkoang.

Keterangan: Angka yang diikuti dengan huruf yang berbeda menunjukkan beda nyata pada $p<0,05$.

\section{Pengaruh Konsentrasi Tapioka dan Gliserol terhadap Karakteristik Mekanik Edible Film dari Pati Bengkoang \\ Karakteristik mekanik merupakan} parameter penting dalam menentukan sifat edible film. Karakteristik mekanik yang diuji adalah kuat tarik, persen pemanjangan, dan laju transmisi uap air.

\section{Kuat Tarik}

Gambar 6 memperlihatkan bahwa semakin tinggi konsentrasi tapioka nilai kuat tarik edible film dari pati bengkoang juga semakin tinggi sedangkan peningkatan gliserol menyebabkan penurunan nilai kuat tarik edible film. Edible film pada konsentrasi tapioka 3\% mempunyai nilai kuat tarik yang paling tinggi sebesar 25,68 MPa. Hal tersebut disebabkan jumlah padatan terlarut yang lebih banyak membuat ikatan silang pada polimer pati yang terbentuk semakin rapat sehingga diperlukan gaya yang lebih besar untuk menarik edible film hingga putus. Semakin rendah konsentrasi pati 
maka ikatan intermolekuler yang terbentuk menjadi kurang kuat dibandingkan dengan konsentrasi pati yang tinggi (Bastioli, 2005).

Hasil tersebut juga sesuai dengan pernyataan Krochta et al. (1994), bahwa kuat tarik dari suatu edible film akan meningkat seiring dengan meningkatnya konsentrasi pati yang ditambahkan.

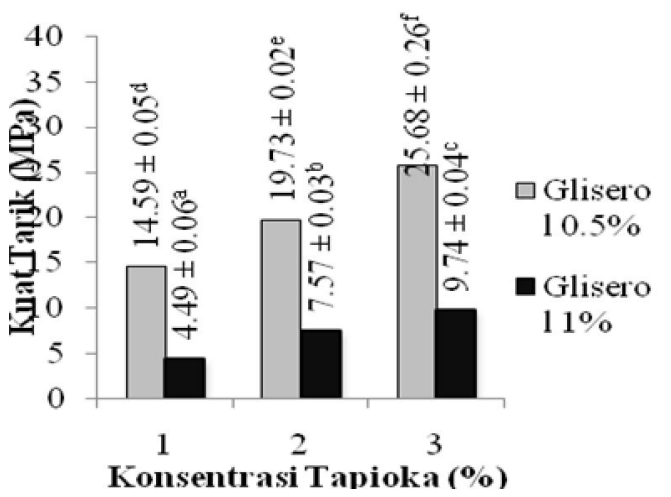

Gambar 6. Pengaruh konsentrasi tapioka dan gliserol terhadap kuat tarik edible film dari pati bengkoang.

Keterangan: Angka yang diikuti dengan huruf yang berbeda menunjukkan beda nyata pada $p<0,05$.

Edible film pada konsentrasi gliserol 1\% menghasilkan kuat tarik yang lebih rendah dibandingkan edible film dengan konsentrasi gliserol $0.5 \%$ (Gambar 6). Hal tersebut disebabkan semakin banyak konsentrasi gliserol yang berkontribusi pada edible film membuat struktur polimer pada pati tidak kokoh sehingga kemampuan interaksi antarmolekul menurun. Hasil tersebut sesuai dengan Chang (2006) yang melaporkan bahwa semakin tinggi konsentrasi gliserol yang berfungsi sebagai plasticizer maka nilai kuat tarik edible film akan semakin menurun. Menurut Han (2004), gliserol bersifat hidrofilik akan melemahkan struktur dari ikatan hidrogen pada pati sehingga cenderung menurunkan kemampuan interaksi antarmolekul.

\section{Persen Pemanjangan}

Gambar 7 menunjukkan peningkatan konsentrasi tapioka hingga 2\% meningkatkan persen pemanjangan film seiring dengan peningkatan gliserol dari $0.5 \%$ hingga $1 \%$. Hal yang berbeda terjadi pada konsentrasi tapioka $3 \%$ dengan persen pemanjangan yang mengalami penurunan. Konsentrasi pati yang tinggi menyebabkan persen pemanjangan menjadi lebih rendah.

Persen pemanjangan paling tinggi terdapat pada edible film yang dihasikan dengan konsentrasi tapioka $2 \%$ seperti yang terlihat pada Gambar 7. Hal tersebut disebabkan pada konsentrasi tapioka $2 \%$ jumlah padatan terlarut pada edible film diiringi dengan gliserol $1 \%$ dan pati bengkoang $1 \%$ dapat meregangkan ikatan polimer pada pati sehingga edible film yang dihasilkan lebih fleksibel. Peregangan ikatan polimer pati yang dipengaruhi oleh gliserol dan pati berperan dalam peningkatan persen pemanjangan. Menurut Djaprie (1995), semakin tinggi konsentrasi pati yang ditambahkan maka struktur edible film menjadi lebih padat dan mudah dipecah atau dirusak.

Gambar 7 menunjukkan bahwa semakin tinggi konsentrasi gliserol maka persen pemanjangan yang dihasilkan juga semakin tinggi. Persen pemanjangan tertinggi terdapat pada konsentrasi gliserol $1 \%$. Hal tersebut dapat disebabkan konsentrasi plasticizer yang semakin tinggi dapat memperbanyak jumlah ikatan polimer-plasticizer yang terbentuk sehingga fleksibilitas edible film meningkat yang ditandai dengan persen pemanjangan yang semakin tinggi. Alasan tersebut didukung oleh Janssen dan Moscicki (2009) yang menyatakan peningkatan gliserol sebagai plasticizer dapat menambah kemampuan fleksibilitas edible film sehingga meningkatkan nilai persen pemanjangan.

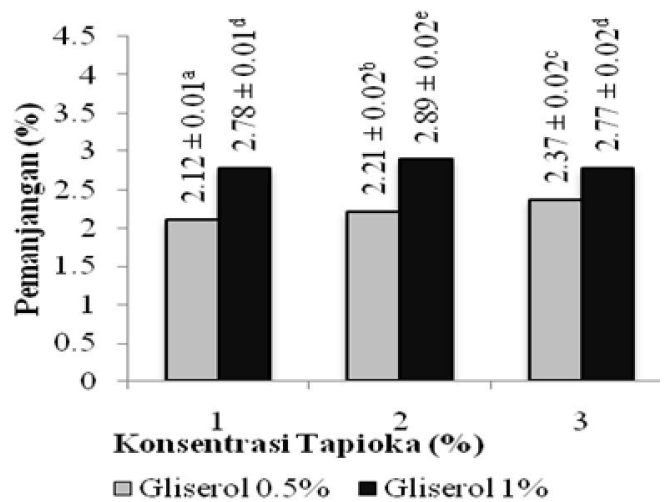

Gambar 7. Pengaruh konsentrasi tapioka dan gliserol terhadap persen pemanjangan edible film dari pati bengkoang

Keterangan: Angka yang diikuti dengan huruf yang berbeda menunjukkan beda nyata pada $p<0.05$

\section{Laju Transmisi Uap Air}

Gambar 8 menunjukkan bahwa peningkatan konsentrasi tapioka seiring dengan peningkatan konsentrasi gliserol maka laju transmisi uap air juga semakin tinggi. Tapioka merupakan golongan polisakarida dan bersifat hidrofilik. Sifat hidrofilik tersebut membuat edible film memiliki laju transmisi uap air yang tinggi seiring dengan peningkatan jumlah tapioka yang ditambahkan. Hal tersebut didukung oleh Irianto 
et al. (2006) yang melaporkan bahwa bahan yang bersifat hidrofilik akan meningkatkan laju transmisi uap air pada edible film.

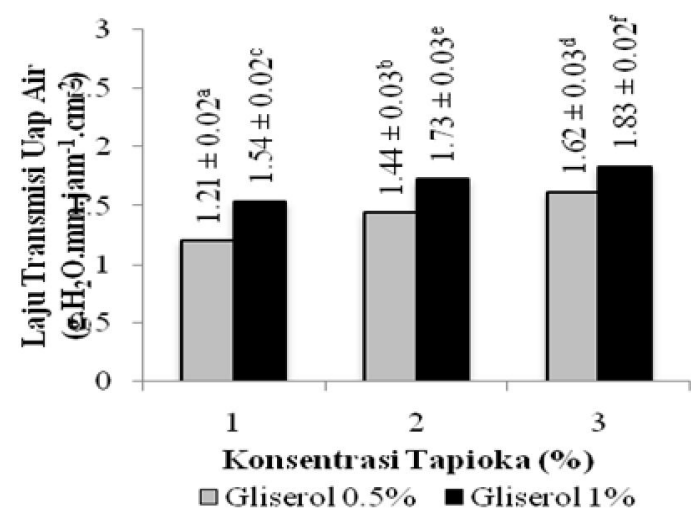

Gambar 8. Pengaruh konsentrasi tapioka dan gliserol terhadap laju transmisi uap air edible film dari pati bengkoang.

Keterangan: Angka yang diikuti dengan huruf yang berbeda menunjukkan beda nyata pada $p<0,05$.

Laju transmisi uap air edible film yang meningkat dengan meningkatnya konsentrasi gliserol (Gambar 8) dapat disebabkan gliserol yang merupakan plasticizer yang bersifat hidrofilik.

Sifat hidrofilik yang dimiliki gliserol memicu meningkatnya laju transmisi uap air. Hal tersebut didukung oleh Al-Hassan dan Norziah (2012) yang melaporkan bahwa plasticizer yang bersifat hidrofilik seperti gliserol dan sorbitol dapat menyebabkan laju transmisi uap air menjadi tinggi pada edible film berbasis hidrokoloid.

\section{Penentuan Edible Film dengan Karakteristik Terbaik pada Tahap I}

Penentuan konsentrasi tapioka dan gliserol terbaik untuk edible film dari pati bengkoang didasarkan pada karakteristik edible film tersebut. Parameter utama pada tahap I yang menentukan edible film dari pati bengkoang adalah karakteristik mekanik. Karakteristik mekanik tersebut adalah kuat tarik dan persen pemanjangan. Konsentrasi tapioka dan gliserol yang dijadikan sebagai faktor berpengaruh terhadap kuat tarik dan persen pemanjangan edible film.

Menurut Mali et al. (2005) dan Fama et al. (2005), pati dan gliserol berpengaruh pada karakteristik mekanik pada edible film. Konsentrasi tapioka $2 \%$ dan gliserol 0,5\% dipilih sebagai konsentrasi terbaik karena kuat tarik yang cukup tinggi yaitu 19,73 MPa dan persen pemanjangan yang cukup baik yaitu $2,21 \%$ dibandingkan dengan konsentrasi tapioka 3\% dan gliserol $0,5 \%$ namun tapioka $3 \%$ dan gliserol $0,5 \%$ tidak dipilih sebagai konsentrasi terbaik karena memiliki laju transmisi uap air dan ketebalan yang cukup tinggi. Oleh karena itu edible film dengan karakteristik fisik dan mekanik terbaik pada tahap I adalah edible film dengan konsentrasi tapioka $2 \%$ dan gliserol $0,5 \%$.

\section{Hasil Penelitian Tahap II}

Penelitian tahap II membuat edible film dengan konsentrasi terbaik pada tahap I dengan penambahan 2 jenis asam lemak. Tujuan penelitian tahap II adalah menentukan jenis asam lemak yang menghasilkan edible film dari pati bengkoang dengan karakteristik fisik dan mekanik terbaik.

\section{Pengaruh Jenis Asam Lemak terhadap Karakteristik Fisik Edible Film dari Pati Bengkoang}

Pembuatan edible film pada tahap II dilakukan dengan konsentrasi tapioka $2 \%$ dan gliserol $0,5 \%$ dengan asam lemak stearat dan asam lemak oleat. Karakteristik fisik edible film yang diuji pada tahap II adalah ketebalan dan lightness.

\section{Ketebalan}

Gambar 9 menunjukkan bahwa edible film yang dihasilkan dengan penambahan asam lemak stearat dan asam lemak oleat memiliki ketebalan yang sama. Asam lemak stearat dan asam lemak oleat tidak mempengaruhi ketebalan edible film dari pati bengkoang.

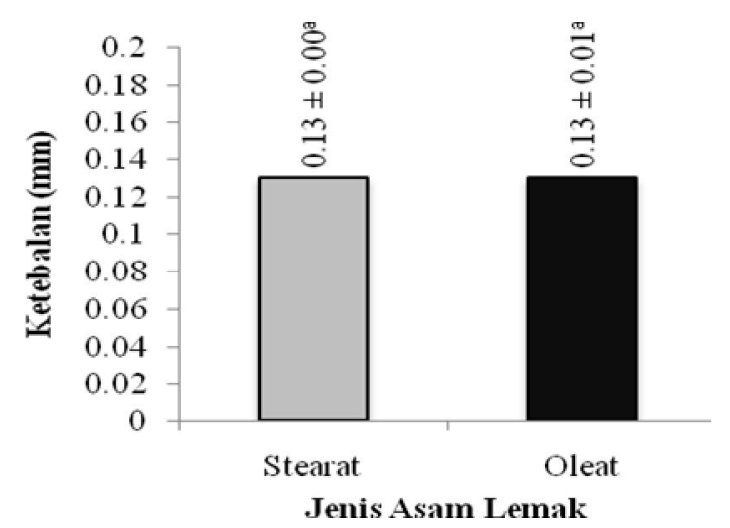

Gambar 9. Pengaruh jenis asam lemak terhadap ketebalan edible film dari pati bengkoang.

Keterangan: Angka yang diikuti dengan huruf yang berbeda menunjukkan beda nyata pada $p<0,05$. 


\section{Lightness}

Gambar 10 menunjukkan lightness pada edible film dengan penambahan asam lemak oleat lebih rendah dibandingkan dengan asam lemak stearat. Nilai lightness yang tinggi menunjukkan tingkat transparansi yang tinggi pada edible film. Penambahan asam lemak ke dalam film yang terbuat dari hidrokoloid dapat menurunkan tingkat transparansi edible film.

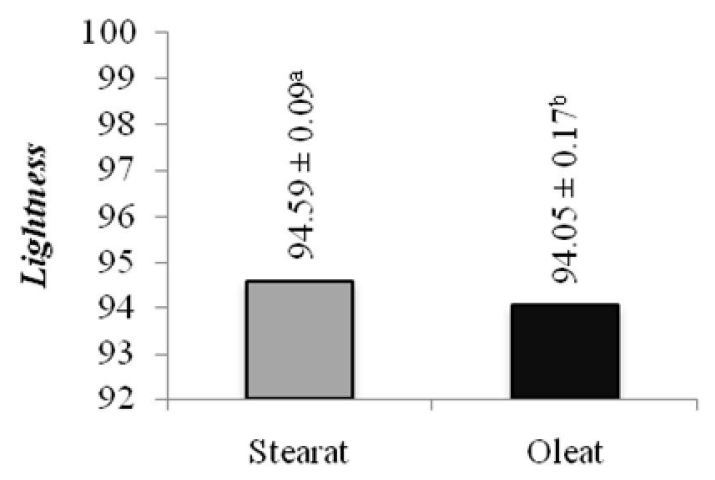

Jenis Asam Lemak

Gambar 10. Pengaruh jenis asam lemak terhadap lightness edible film dari pati bengkoang.

Keterangan: Angka yang diikuti dengan huruf yang berbeda menunjukkan beda nyata pada $p<0,05$.

Pengaruh Jenis Asam Lemak terhadap Karakteristik Mekanik Edible Film dari Pati Bengkoang

Karakteristik mekanik pada edible film merupakan parameter penting dalam menentukan karakteristik dari edible film tersebut.

\section{Kuat Tarik}

Gambar 11 menunjukkan bahwa kuat tarik pada edible film dengan penambahan asam stearat lebih tinggi daripada edible film dengan penambahan asam lemak oleat.

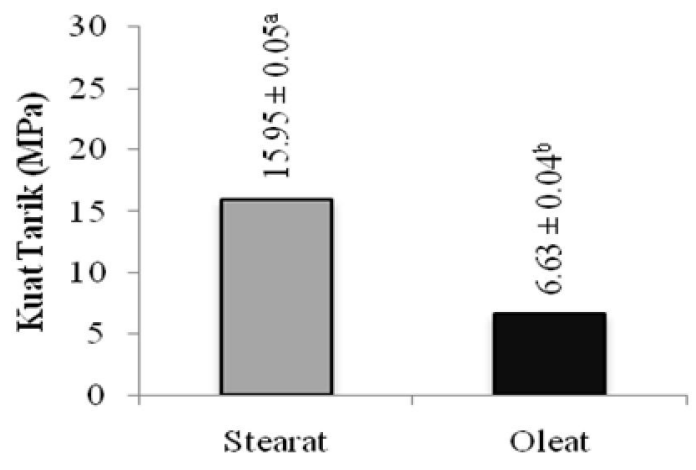

Jenis Asam Lemak

Gambar 11. Pengaruh jenis asam lemak terhadap kuat tarik edible film dari pati bengkoang.

Keterangan: Angka yang diikuti dengan huruf yang berbeda menunjukkan beda nyata pada $p<0,05$.
Asam stearat memiliki sifat hidrofobik lebih tinggi sehingga penambahan asam stearat pada edible film berpengaruh terhadap struktur dari film yang dihasilkan.

Struktur polimer matriks pada edible film menjadi lebih kuat ketika berikatan dengan struktur hidrofobik dari asam lemak stearat. Hal tersebut menyebabkan kuat tarik pada edible film yang ditambahkan asam stearat lebih tinggi. Hal tersebut didukung oleh Fernandez et al. (2007) yang melaporkan bahwa penambahan asam lemak stearat menghasilkan edible film dengan kuat tarik yang lebih tinggi.Edible film dengan penambahan asam lemak oleat memiliki nilai kuat tarik yang lebih rendah jauh dibandingkan edible film dengan penambahan asam lemak stearat seperti yang terlihat pada Gambar 11.

Asam lemak oleat merupakan asam lemak tak jenuh dengan sifat hidrofilik yang lebih tinggi daripada asam lemak stearat. Asam lemak oleat yang bergabung dengan ikatan polimer pati bengkoang dan tapioka menghasilkan edible film yang lebih rapuh dibandingkan dengan asam lemak stearat.

Hal tersebut disebabkan asam lemak oleat mempunyai sifat hidrofilik lebih tinggi dibandingkan dengan asam lemak stearat. Asam lemak oleat menyebabkan diskontinuitas matriks polimer edible film yang berdampak pada penurunan kekuatan kohesi polimer sehingga kuat tarik menjadi lebih rendah (Jimenez et al., 2012).

\section{Persen pemanjangan}

Gambar 12 menunjukkan bahwa persen pemanjangan pada edible film dengan penambahan asam oleat lebih tinggi dibandingkan dengan penambahan asam lemak stearat. Hal tersebut dapat disebabkan asam oleat yang memiliki sifat polaritas lebih tinggi dibandingkan asam lemak stearat sehingga lebih dapat berikatan dengan gliserol dan bertindak sebagai plasticizer dalam matriks pati yang membuat edible film menjadi lebih fleksibel sebaliknya persen pemanjangan pada edible film yang ditambahkan asam lemak stearat mengalami penurunan.

Asam lemak stearat yang berbentuk padat tersebar dalam matriks polimer pati secara makro sehingga distribusi partikel kurang baik. Hal tersebut juga dapat disebabkan oleh sifat hidrofobik yang dimiliki oleh asam lemak stearat yang memicu distribusi partikel pada matriks polimer pati yang tidak merata. Fleksibilitas dari edible film yang dihasilkan ditandai dengan persen pemanjangan yang semakin tinggi (Jimenez, 2012). 


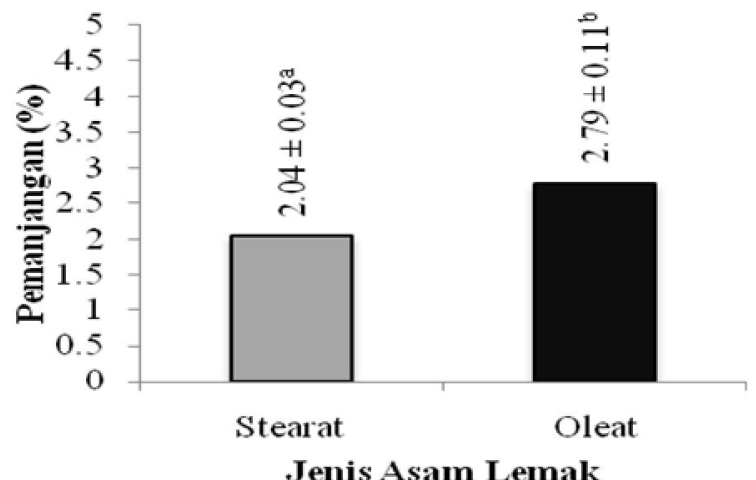

Gambar 12. Pengaruh jenis asam lemak terhadap Pemanjangan edible film dari pati bengkoang.

Keterangan: Angka yang diikuti dengan huruf yang berbeda menunjukkan beda nyata pada $p<0,05$.

\section{Laju Transmisi Uap Air}

Gambar 13 menunjukkan bahwa laju transmisi uap air edible film dengan penambahan asam oleat lebih tinggi daripada edible film yang ditambahkan asam lemak stearat. Hal tersebut menunjukkan bahwa asam oleat kurang baik dalam menurunkan laju transmisi uap air edible film dari pati bengkoang dan tapioka.

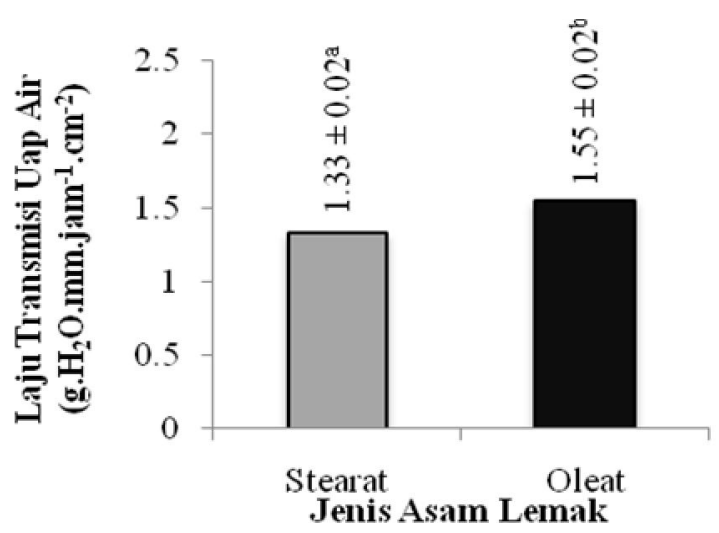

Gambar 13. Pengaruh jenis asam lemak terhadap laju transmisi uap air edible film dari pati bengkoang.

Keterangan: Angka yang diikuti dengan huruf yang berbeda menunjukkan beda nyata pada $p<0.05$

Asam lemak stearat adalah asam lemak jenuh dengan rantai hidrokarbon terpanjang. Asam lemak stearat memiliki mobilitas rantai yang rendah. Sifat hidrofobik dari asam lemak stearat dapat mengurangi laju transmisi uap air dari edible film berbasis polisakarida (Ayranci dan Tunc, 2001).

Asam lemak oleat merupakan asam lemak tak jenuh yang memiliki sifat polaritas lebih tinggi dibandingkan dengan asam stearat. Hal tersebut dapat dilihat pada Gambar 13 yang menunjukkan laju transmisi uap air dari edible film dengan penambahan asam lemak oleat lebih tinggi daripada asam lemak stearat.

Edible film dari pati bengkoang kemungkinan memiliki sifat polaritas yang lebih tinggi dapat mengurangi kekuatan kohesif antar rantai polimer sehingga memicu difusi molekul air. Menurut Fabra et al. (2008) interaksi yang kuat dari kelompok polar asam oleat dan air menyebabkan molekul asam oleat masuk ke matriks polimer film dan menyebabkan gaya tarik menarik antara molekul. Gaya tarik-menarik tersebut menyebabkan kohesif antarrantai polimer menurun.

\section{Penentuan Edible Film dengan Karakteristik Terbaik pada Tahap II}

Penentuan edible film dari pati bengkoang dengan karakteristik terbaik pada tahap II didasarkan pada karakteristik mekanik yaitu laju transmisi uap air. Perlakuan asam lemak yang ditambahkan pada edible film bertujuan untuk memperbaiki karakteristik laju transmisi uap air sehingga karakteristik laju transmisi uap air dijadikan sebagai penentu jenis asam lemak terbaik pada tahap II. Menurut Ayranci dan Tunc (2001), tujuan utama penambahan asam lemak adalah menurunkan laju transmisi uap air.

Edible film yang ditambahkan asam lemak stearat memiliki laju transmisi uap air yang lebih rendah dibandingkan dengan edible film yang ditambahkan asam lemak oleat. Penambahan asam lemak stearat dan asam lemak oleat menghasilkan edible film dengan ketebalan hampir sama sehingga ketebalan tidak dipengaruhi oleh jenis asam lemak. Edible film yang ditambahkan asam lemak stearat memiliki kuat tarik yang lebih tinggi dan persen pemanjangan yang lebih rendah dibandingkan dengan edible film yang ditambahkan asam lemak oleat. Oleh karena itu edible film dengan karakteristik fisik dan mekanik terbaik pada tahap II adalah edible film dari pati bengkoang dengan penambahan asam lemak stearat.

\section{KESIMPULAN}

Edible film dari pati bengkoang memiliki karakteristik fisik dan mekanik terbaik pada konsentrasi tapioka $2 \%$ dan gliserol $0,5 \%$. Edible film tersebut memiliki kuat tarik dan persen 
pemanjangan yang cukup baik walaupun laju transmisi uap airnya kurang baik. Penambahan asam lemak stearat dapat memperbaiki laju transmisi uap air edible film dari pati bengkoang walaupun disertai dengan penurunan persen pemanjangan.

\section{DAFTAR PUSTAKA}

Al-Hassan A. A. and M. H. Norziah. 2012. Starch-gelatin edible films: Water vapor permeability and mechanical properties as affected by plasticizers. Food Hydrocolloid 26 (1): 108-117.

Ayranci E. and Tunc S. 2001. The effect of fatty acid content on water vapor and carbon dioxide transmission of cellulose-based edible film. Food Chemistry 72 (2): 231236.

Baker, R., E. Baldwin and M. Nisperos-Carriedo. 1994. Edible coatings and films for processed foods. In Journal M. Krochta, E. A. Baldwin, \& M. O. NisperosCarriedo (Eds.), Edible Coatings and Films to Improve Food Quality pp. 89104. New York: Technomic Publishing Co., Inc.

Chang, Y. P., A. Abd Karim, and C. C. Seow. 2006. Interactive plasticizingantiplasticizing effects of water and glycerol on the tensile properties of tapioca starch films. Food Hydrocolloid 20 (1): 1-8.

Chen, C. H. and L. S. Lai. 2008. Mechanical and water vapor barrier properties of tapioca starch decolorized hsian-tsao leaf gum films in the presence of plasticizer. Food Hydrocolloids 22 (8): 1584-1595.

Chen, C. H, W. S. Kuo, and L. S. Lai. 2009. Effect of surfactants on water barrier and physical properties of tapioca starch/decolorized hsian-tsao leaf gum films. Food Hydrocolloids 23 (3): 714721.

Fabra, M. J., P. Talens, and A. Chiralt. 2008. Tensile properties and water vapor permeability of sodium caseinate film containing oleicacid-beeswax mixtures. Journal of Food Engineering 85 (3): 393400

Fernandez, L., E. D. Apodaca, M. Cebrian, M. C. Villaran, and J. I. Mate. 2007. Effect of the unsaturation degree and concentration of fatty acids on the properties of WPI-based edible films. Euro Food Res Technol 224: 415-420.

Fama,LRojas, S. Goyanes, and L. Gerschenson. 2005. Mechanical properties of tapiocastarch edible films containing sorbates.
LWT 38 (6): 631-639.

Han, C., Y. Zhao, S. W. Leonard, and M. G. Traber. 2004. Edible coatings to improve storability and enhance nutritional value of fresh and frozen strawberries (Fragaria $\times$ ananassa) and raspberries (Rubus ideaus). Post Harvest Biology and Technology 33 (1): 67-78.

Irianto, H. E., Darmawan, M., dan Mindarwati, E. 2006. Pembuatan edible film komposit karaginan, tepung tapioka, dan lilin lebah (bees wax). Jurnal Pascapanen dan Bioteknologi Kelautan dan Perikanan 2 (1): 93-101.

Janssen, L. P. B. M and Moscicki, L. 2009. Thermoplastic Starch: A Green Material forVarious Industries. Weinheim: Wiley$\mathrm{VCH}$.

Jimenez, A., M. J. Fabra, P. Talens, dan A. Chiralt. 2012. Effect of re-crystallization on tensile, optical and water vapor barrier properties of corn starch films containing fatty acids. Food Hydrocolloid 26 (1): 302-310.

Krochta, J. M. and C. De Mulder-Johnston. 1997. Edible and biodegradable polymer films: challenges and opportunities. Food Technology 51 (2): 61-74

Mali, S., M. V. E. Grossmann, M. A. Garcia, M. A. Martino, M. N., and N. E. Zaritzky. 2005. Mechanical and thermal properties of yam starch films. Food Hydrocolloid 19 (1): 157-164.

Matsui, K.N.,F.D.S. Larotonda,S.S. Paes,D.B. Luiz, A. T. N. Pires, and J. B. Laurindo. 2004. Cassava bagasse-Kraft paper composites: analysis of influence of impregnation with starch acetate on tensile strength and water absorption properties. Carbohydrates Polymers 55 (3): 237-243.

Suryadi M. O. Aplikasi Pati Ganyong dan Gliserol sebagai Edible Coating pada Stroberi (Fragaria ananasa). Skripsi. Jurusan Teknologi Pangan, UPH, Tangerang, 2011.

Wang, X., X. Sun, H. Liu, M. Li, and Z. Ma. 2011. Barrier and mechanical properties of carrot puree films. Food and Bioproducts Processing 89 (2): 149-156. 